Roger Williams University

DOCS@RWU

2013

\title{
Uncovering an Obscure Trade: Threatened Freshwater Fishes and the Aquarium Pet Markets
}

\author{
Rajeev Raghavan \\ University of Kent, Canterbury, U.K \\ Neelesh Dahanukar \\ Zoo Outreach Organization, India \\ Michael F. Tlusty \\ New England Aquarium, John H Prescott Marine Laboratory, U.S.A \\ Andrew L. Rhyne \\ Roger Williams University, arhyne@rwu.edu \\ K. Krishna Kumar \\ St. Albert's College, Kochi, India
}

See next page for additional authors

Follow this and additional works at: https://docs.rwu.edu/fcas_fp

Part of the Biology Commons

\section{Recommended Citation}

Raghaven, R., D. Dahanukar, M. Tlusty, A.L. Rhyne, et al. 2013. "Uncovering an Obscure Trade: Threatened Freshwater Fishes and the Aquarium Pet Markets." Biological Conservation 164: 158-169.

This Article is brought to you for free and open access by the Arts and Sciences at DOCS@RWU. It has been accepted for inclusion in Arts \& Sciences Faculty Publications by an authorized administrator of DOCS@RWU. For more information, please contact mwu@rwu.edu. 


\section{Authors}

Rajeev Raghavan, Neelesh Dahanukar, Michael F. Tlusty, Andrew L. Rhyne, K. Krishna Kumar, Sanjay Molur, and Alison M. Rosser 


\title{
Uncovering an obscure trade: Threatened freshwater fishes and the aquarium pet markets
}

\author{
Rajeev Raghavan a,b,c,d,*, Neelesh Dahanukar ${ }^{\text {e,f }}$, Michael F. Tlusty ${ }^{g}$, Andrew L. Rhyne ${ }^{\text {g,h }}$, \\ K. Krishna Kumar ${ }^{\text {b,i }}$, Sanjay Molur ${ }^{\mathrm{e}}$, Alison M. Rosser ${ }^{\mathrm{j}}$ \\ a Durrell Institute of Conservation and Ecology (DICE), School of Anthropology and Conservation, University of Kent, Canterbury, United Kingdom \\ ${ }^{\mathrm{b}}$ Conservation Research Group (CRG), St. Albert's College, Kochi, India \\ ${ }^{\mathrm{c}}$ Research Group Zoology: Biodiversity and Toxicology, Center for Environmental Sciences (CMK), University of Hasselt, Diepenbeek, Belgium \\ ${ }^{\mathrm{d}}$ Institute of Aquaculture, Faculty of Fisheries and Protection of Waters, University of South Bohemia, Ceske Budejovice, Czech Republic \\ e Zoo Outreach Organization (ZOO), 96, Kumudham Nagar, Vilankurichi Road, Coimbatore, India \\ ${ }_{\mathrm{f}}^{\mathrm{f}}$ Indian Institute of Science Education and Research (IISER), Pune, India \\ ${ }^{\mathrm{g}}$ New England Aquarium, John H Prescott Marine Laboratory, Boston, MA, United States \\ ${ }^{\mathrm{h}}$ Department of Biology and Marine Biology, Roger Williams University, Bristol, RI, United States \\ ${ }^{\mathrm{i}}$ Community Environmental Resource Center (CERC), Ashoka Trust for Research in Ecology and Environment (ATREE), Alleppey, India \\ ${ }^{j}$ Species Programme, United Nations Environment Programme-World Conservation Monitoring Center (UNEP-WCMC), Cambridge, United Kingdom
}

\section{A R T I C L E I N F O}

\section{Article history:}

Received 10 September 2012

Received in revised form 30 January 2013

Accepted 23 April 2013

Available online 19 June 2013

\section{Keywords:}

Aquarium trade

Biodiversity hotspots

Conservation

Endemic

Red Lined Torpedo Barb

\begin{abstract}
A B S T R A C T
While the collection of fish for the aquarium pet trade has been flagged as a major threat to wild populations, this link is tenuous for the unregulated wild collection of endemic species because of the lack of quantitative data. In this paper, we examine the extent and magnitude of collection and trade of endemic and threatened freshwater fishes from India for the pet markets, and discuss their conservation implications. Using data on aquarium fishes exported from India, we try to understand nature of the trade in terms of species composition, volume, exit points, and importing countries. Most trade in India is carried out under a generic label of "live aquarium fish"; yet despite this fact, we extracted export data for at least thirty endemic species that are listed as threatened in the IUCN Red List. Of the 1.5 million individual threatened freshwater fish exported, the major share was contributed by three species; Botia striata (Endangered), Carinotetraodon travancoricus (Vulnerable) and the Red Lined Torpedo Barbs (a species complex primarily consisting of Puntius denisonii and Puntius chalakkudiensis, both 'Endangered'). Using the endangered Red Lined Torpedo Barbs as a case study, we demonstrate how existing local regulations on aquarium fish collections and trade are poorly enforced, and are of little conservation value. In spite of the fact that several threatened and conservation concern species are routinely exported, India has yet to frame national legislation on freshwater aquarium trade. Our analysis of the trade in wild caught freshwater fishes from two global biodiversity hotspots provides a first assessment of the trade in endangered and threatened species. We suggest that the unmanaged collections of these endemic species could be a much more severe threat to freshwater biodiversity than hitherto recognized, and present realistic options for management.
\end{abstract}

(c) 2013 Elsevier Ltd. All rights reserved.

\section{Introduction}

The aquarium fish trade is a large, biodiverse, global industry (Tlusty et al., 2013), worth around 15-30 billion US\$ (Penning et al., 2009) and involving $~ 5300$ freshwater and 1802 marine fish (Hensen et al., 2010; Rhyne et al., 2012a). Ninety percent of the trade volume revolves around tropical freshwater fishes of which

\footnotetext{
* Corresponding author at: Durrell Institute of Conservation and Ecology (DICE), School of Anthropology and Conservation, University of Kent, Canterbury, United Kingdom. Tel.: +44 754061435.

E-mail address: rajeevraq@hotmail.com (R. Raghavan).
}

all but $10 \%$ are captive bred, and the remainder comprise of diverse wild-caught species (Olivier, 2001).

Collection of freshwater fishes for the aquarium trade is also a practice that divides opinion (Watson and Moreau, 2006). While some authors consider them an important contributor to local economies that can provide incentives for environmental conservation if well managed (Tlusty et al., 2008; see also Rhyne et al., 2012b for a marine example), others question its sustainability vis-à-vis the unmanaged nature and population decline of important species (FAO, 2003; Gerstner et al., 2006; Moreau and Coomes, 2007; Rowley et al., 2008). For example, in Malawi, South Eastern Africa, collection of aquarium fish has been known to support the 
employment of at least 1500 people (SM. Grant cited in Helfman, 2007). But on the other hand, it has been demonstrated that profitable aquarium trade cannot be sustained on the basis of wild caught freshwater fish in Cameroon (Brummet et al., 2010), and that around 82 species of African freshwater fishes seen in the aquarium trade are threatened (UNEP-WCMC, 2008). Moreau and Coomes (2007) while acknowledging that $\sim 10,000$ people in the Iquitos region of Peru earned at least some income from collecting aquarium fishes, also cautions that the trade presents new conservation concerns. Similarly, Gerstner et al. (2006) estimated that 3000 families made a living from the trade and that 100,000 people benefited economically in Peruvian villages, where few other economic opportunities were available. Yet, there was no evidence to support that wild caught aquarium trade was sustainable, and added that anecdotal evidence indicated that the number of species available was declining.

In India, the country that harbours the most number of endemic freshwater fishes in continental Asia (Froese and Pauly, 2012), collection of such species for the aquarium trade is entirely openaccess, unregulated and even encouraged by certain governmental and semi-governmental agencies (Raghavan, 2010). Most wild caught aquarium fish originating from India come from the Eastern Himalaya and Western Ghats, hotspots known for their remarkable freshwater biodiversity and endemism (Allen et al., 2010; Molur et al., 2011). Approximately 200 species of freshwater fish from the Eastern Himalaya have been collected for the trade, although less than half are exported regularly (Allen et al., 2010). Similarly, of more than 100 species that have entered the trade from Western Ghats (Raghavan, 2010), close to two dozen are regularly exported. The remaining species are non-viable in trade as they are rare, and therefore extremely hard to collect and thus cannot meet a constant market demand, or are extremely sensitive to handling and transportation.

At the centre of attraction of India's aquarium trade are the charismatic Red Lined Torpedo Barbs (RLTBs), a species complex of colourful cyprinids, whose unmanaged collection during the last two decades is associated with severe population declines, and an 'Endangered' listing in the IUCN Red List of Threatened Species (Ali et al., 2011; Raghavan and Ali, 2011). The increasing global attention on the need for conservation of RLTBs led the Department of Fisheries in the southern Indian state of Kerala to issue a Government Order in 2008, restricting collection and exports, and proposing several management measures including quotas, gear restrictions, minimum catch size, and a seasonal trade ban (Mittal, 2009). However, recent studies indicate that these regulations were developed with minimum scientific input and offer little protection for the species (Solomon et al., 2011). For example, a seasonal closure of the fishery was implemented based on the assumption that the RLTBs breed in June, July and October (Clarke et al., 2009). However, research on biology of the species showed that the actual breeding season extends from October to March, and that the seasonal closure is therefore mistimed (Solomon et al., 2011). In general, efforts to manage collection and exports of freshwater aquarium fishes in India have been hindered by the lack of empirical data about the trade.

The status of freshwater fish as 'wildlife' and its conservation is also somewhat anomalous in India. The main wildlife conservation legislations in India are the Wildlife Protection Act (1972), which lists protected species and prescribes regulations for hunting or harvesting wild animals; the Biological Diversity Act (2002), which implements aspects of the Convention on Biological Diversity (CBD) and the Indian Forest Act (1927), which provides for habitat protection and use of forest products. None of these legislations relate explicitly to the conservation of freshwater fish. Several states have also passed 'Inland Fisheries' acts (Dahanukar et al., 2011), but without any focus on conservation and sustainable use of aquarium fishes. In general, freshwater fish is viewed as an open access resource, and a free commodity that can be collected from nature (Raghavan, 2010), resulting in the precarious state of freshwater biodiversity (Allen et al., 2010; Molur et al., 2011).

In this paper, we assess the levels of exports of threatened freshwater fishes from India for the aquarium trade, while specifically focusing on the endangered RLTBs. For the first time, we provide information on species, export quantities, trade routes, airports and importing countries. Where data allow, we also examine the impacts of trade on the conservation of these endangered species.

\section{Materials and methods}

The official export records of aquatic animals in India, maintained by the Marine Products Exports Development Authority (MPEDA) under the Central Ministry of Commerce, contains only a general quantification of aquarium fish exports and does not provide details of common names, genera, or species (see MPEDA, 2010). Currently, there is also no legislation or official reporting system in place that requires the declaration of 'species' or their 'numbers' prior to export. It is known that while some individual exporters do provide data on the details of the cargo (species and numbers), others simply list aquarium fish exports under the general label 'live ornamental fish' or 'tropical freshwater fish' (see Smith et al., 2008). Some airports in India (e.g., Bangalore/Bengaluru/BLR) require the labelling of consignments at the genus/species level before exports, while others (e.g., Kochi/Cochin/COK) do not. Exporters may also declare the names of species (and their size ranges) during export due to such requirements from the importers side. However, such information is not passed onto the MPEDA for aggregation in a database.

Our search for detailed information on aquarium fish exports from India led us to Tips Software Service Private Limited, a company that maintains a database on export and import related information including foreign trade statistics (see www.dailyexportimportdata.com). The company collects data on all commodities exported from India including live animals, from the customs records available at various airports and seaports. Using the database at Tips, we obtained customs-level data on the daily exports of aquarium fishes from the international airports in India from April 2005 until March 2012.

For the present study, we considered only freshwater fish. All species of marine and brackishwater fishes, as well as freshwater shrimps were excluded. Data were extracted in the form of a matrix with information regarding date of export, descriptive label on the cargo (species/trade name, or general label such as 'live ornamental fish', 'ornamental live fish', 'live aquarium fish', 'live aquarium ornamental fish', 'ornamental fish', 'assorted live ornamental fish'), export and import airports, quantity, size ranges (wherever mentioned by the exporter) and units (under four categories: 'PCS', pieces; 'NOS', numbers; 'DOZ', dozen; 'KGS', kilograms). After consulting with the data provider, the units 'PCS' and NOS were considered as same, which indicated the number of individuals in the cargo. Unit 'DOZ' was converted to 'NOS' by multiplying the value by 12 . Since it was not possible to decipher the number of individuals shipped as KGS, we omitted this data from the analysis of numbers in trade. However, we did a separate analysis on the data in KGS so as to decipher the volume of trade in KGS. Currency exchange rates (Indian Rupee to US Dollar) during the years covered by the study were obtained from http:// www.oanda.com/currency/historical-rates/.

Additional information on the trade was gathered during field research in the Western Ghats, in retail shops in Europe and South East Asia, and extensive internet searches for aquarium fish 
retailers, importers and exporters at various intervals during 2006-2012. Semi-structured interviews consisting of open-ended questions (Newing, 2010) aimed at obtaining information on species harvested, their numbers, collection techniques, demand, supply and marketing channels were obtained from both collectors $(n=7)$ and exporters $(n=4)$. Five collectors and three exporters operated from the Western Ghats region, while two collectors and one exporter were active in the Eastern Himalaya/North East Indian landscape. All respondents agreed to be interviewed and gave their consent for participating in the study. They were also told that the information provided will be subsequently used for publication, and available in the public domain. The scientific name of the harvested species was always validated, after the collectors confirmed them (via their common names) through the photographs that we provided. An additional seven collectors and two exporters (for whom these collectors worked) refused to be interviewed.

The first author visited retail shops in Malaysia (2006, 2012), Singapore (2010), Thailand (2011), Hong Kong (2011), Germany (2010, 2011), Belgium (2011, 2012), Netherlands (2009, 2011) and the United Kingdom $(2009,2010,2011,2012)$ to get first-hand information on the species originating from Western Ghats that are available in these markets. A list of species available in these retail shops was subsequently compiled, by combining the names of species encountered in these outlets during random (personal) visits, and those obtained after discussions with the retailer as having been imported from India and/or originating from India. Websites of wholesalers and retailers in US, Europe and South East Asia were also accessed at random intervals during 2006-2012, and information on the names of freshwater fishes that were both endemic to India, and mentioned as imported from India gathered.

Data on distribution and conservation status of species were retrieved from the IUCN Red List of Threatened Species (www.iucnredlist.org), trade names from Hensen et al. (2010) and scientific names from Eschmeyer (2012) and Pethiyagoda et al. (2012).

\section{Results}

The reported aquarium fish trade exports from India were worth in excess of 1.6 million US\$ for the 7 year period from 2005 to 2012, and were exported from seven exit points to as many as 27 countries (Fig. 1; Appendix A). These exports comprised at least five million aquarium fishes (Fig. 1); (n.b. 4\% of consignments were only reported as KGs and numbers could not be estimated) (see Table 1). While more than $97 \%$ of the exports during

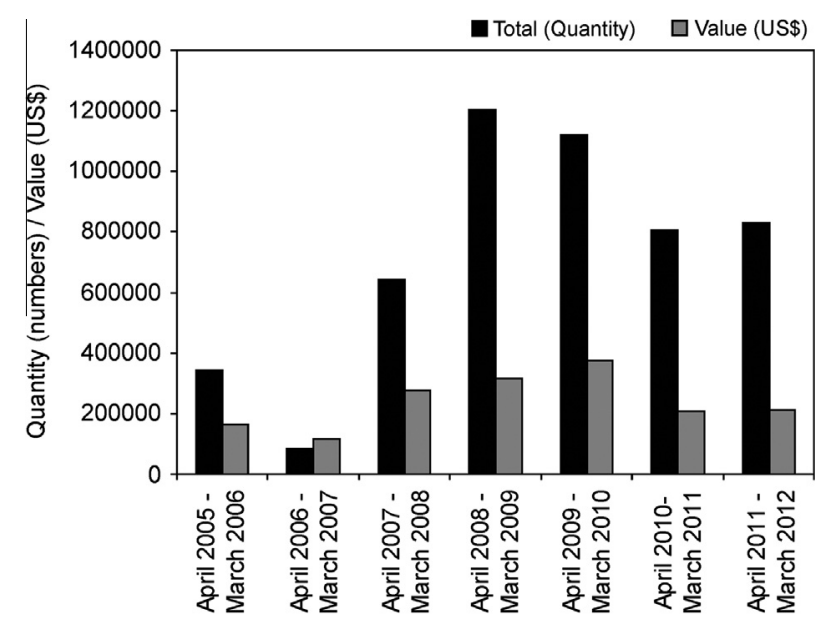

Fig. 1. Quantity and value of aquarium fish exported from India during the years 2005-2012.
2005-2006 comprised of unnamed and unidentified species, this reduced to $13 \%$ during $2011-2012$ (Fig. 2 ).

At least 68 genera and 136 species could be identified as present in the trade during the study period (Appendix B). Of these, names of only 60 genera and 112 species were encountered in the customs records. Names of the additional eight genera and 24 species were obtained as a result of the interviews with collectors and exporters after they revealed their occurrence in trade (see Appendix B). Of these 24 species, four were also recorded by the first author at pet stores in Germany and Singapore (Table 2) while an additional eight were known to be imported to the US through its availability on a wholesaler's website (Table 3).

In addition, the identity of four species (Badis ruber, Channa harcourtbutleri, Macrognathus aculeatus and Parambassis wolffii) which were encountered in the customs database needs further clarification as they are not known to occur in India. They may either be misidentifications on the part of the exporter, or could represent individuals that may have been imported from Myanmar and subsequently re-exported from India.

Fishes were exported under both known species codes and more generic labels such as 'live ornamental fish', 'ornamental live fish', 'live aquarium ornamental fish', 'ornamental fish' or 'assorted live ornamental fish'. Beginning January 2012, cargos are being increasingly labelled under a group name (mostly the generic name or common name such as 'Barb Group'; 'Puntius Group'; 'Catfish Group' and 'Snakehead Group') instead of the more general codes such as 'live aquarium fish'. The reason behind this is not clear as there seems to be neither a legislative requirement, nor any incentive to do so.

\subsection{Threatened species in trade}

More than 1.5 million freshwater fish (30\% of total) belonging to 30 threatened species were exported from India during the years 2005-2012 (Table 2). Of these, Botia striata (Endangered), Carinotetraodon travancoricus (Vulnerable) and the RLTBs, Puntius denisonii and Puntius chalakkudiensis (both species 'Endangered') formed the bulk of exports (Table 2). Range restricted species of conservation concern such as Garra hughi (Endangered) and Channa aurantimaculata (Data Deficient; single location endemic) were also exported. Four of the 30 threatened species, including the recently described Dawkinsia rohani were encountered at retail shops in Germany and Singapore (Appendix B) by the first author, but were not listed in the customs records and so were most likely exported under a generic label. This was also the case with an additional four (threatened) species (Nemacheilus petrubanarescui, Horabagrus nigricollaris, Travancoria elongata and Travancoria jonesi), which were not listed in the customs records, but were revealed by collectors and exporters as being in the trade.

A recent (May 2012) online search for 'Indian native ornamental fishes' helped retrieve information on the export of eight species (seven of them threatened) to the US in April 2012 (Table 3), indicating that new species of conservation concern are being collected and exported to satisfy hobbyist preference for novel and/or rare varieties. Of these eight species, Gonoproktopterus thomassi (Critically Endangered) has an extremely restricted distribution with an area of occupancy of $<10 \mathrm{~km}^{2}$, while Glyptothorax housei (Endangered) has an area of occupancy of $<25 \mathrm{~km}^{2}$ and is restricted to a single location in the Western Ghats Hotspot.

\subsection{Trade in RLTBS}

Over 300,000 RLTBs were exported from India during 20052012 to seven countries (Figs. 3 and 4). The actual number of fish that were collected would probably have been several times higher to compensate the high post-harvest mortality in these species 
Table 1

Details of cargos with aquarium fishes exported from India during the years 2005-2012.

\begin{tabular}{|c|c|c|c|}
\hline Year & Total number of cargos & Number of cargos $(\mathrm{kg})$ & Weight of cargo $(\mathrm{kg})$ \\
\hline April 2005-March 2006 & 473 & 6 & 308.04 \\
\hline April 2006-March 2007 & 290 & 0 & 0 \\
\hline April 2007-March 2008 & 809 & 33 & 4860.08 \\
\hline April 2008-March 2009 & 1218 & 0 & 0 \\
\hline April 2009-March 2010 & 1358 & 6 & 7372.00 \\
\hline April 2010-March 2011 & 1064 & 121 & 31068.00 \\
\hline April 2011-March 2012 & 783 & 82 & 31542.19 \\
\hline Total & 5995 & 248 & 75150.31 \\
\hline
\end{tabular}

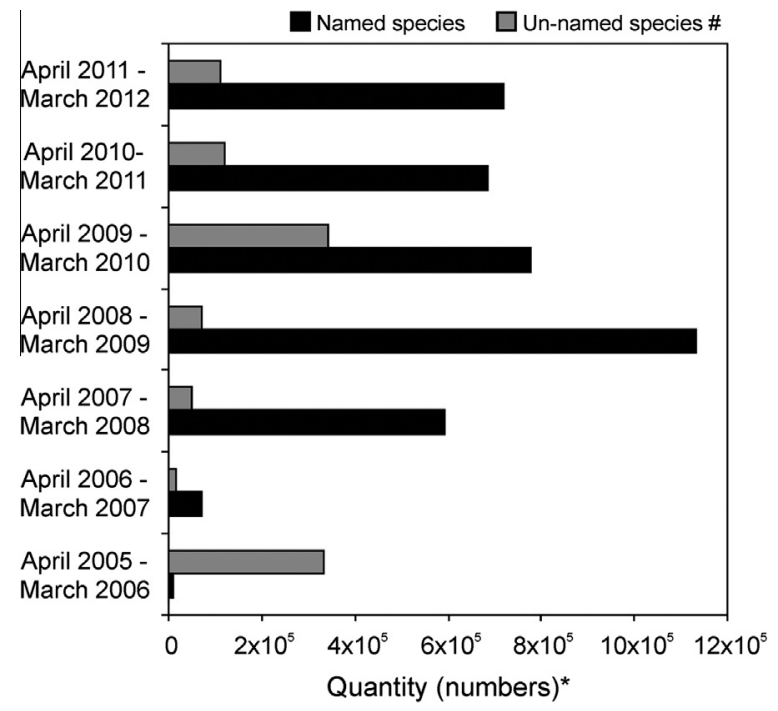

Fig. 2. Quantity of named and unnamed species of freshwater aquarium fish exported from India during the years 2005-2012.

(Ramachandran et al., 2004). Bangalore airport was the hub for the RLTB trade contributing to $96 \%$ of the reported exports followed by
Mumbai, Chennai and Kolkata (Fig. 4). Our export quantification is in all probability under-estimated as only those cargos labelled as either ' $P$. denisonii', 'P. chalakkudiensis' or the 'Red Lined Torpedo Barbs' were included in the analyses. Several thousand RLTBs could have been exported under generic labels (for e.g. live ornamental fish) and/or group labels (Barb/Puntius Group), both in 'PCS' and 'KGS'. One hundred and forty consignments of RLTBs exported during the years 2005-2012 also had information on the size range $(1.70,2-2.5,3$ and 4 in.) of the individual fish.

Singapore (48.63\%), Hong Kong (30.52\%) and Malaysia (18.4\%) were the main markets to which RLTBs were exported during 2005-2012, with negligible quantities exported to Germany, United Kingdom and Japan (Fig. 4).

\section{3. $R L T B$ trade regulations}

Our results suggest that the local regulations (including a ban) on collections and exports of RLTBs implemented in the southern Indian state of Kerala, has been poorly enforced. Although there seemed to have been an immediate impact (during 2009), as indicated by an absence of RLTB in the customs database in the months of the trade ban, these regulations lacked continuity, as at least 11,260 RLTBs were exported during the months of the ban in the subsequent years. This was around $22 \%$ of all RLTBs exported during 2010-2012 (Fig. 5). Collectors $(n=5)$ and exporters $(n=3)$

Table 2

List of threatened and conservation concern endemic freshwater fish species exported from India during the years 2005-2012.

\begin{tabular}{|c|c|c|c|c|}
\hline Species & Trade name & Endemism & IUCN status & Quantity (nos) \\
\hline Barilius canarensis & & WG & EN & 370 \\
\hline Botia rostrata & & $\mathrm{EH}$ & VU & 665 \\
\hline Botia striata & Striped Loach & WG & $\mathrm{EN}^{\mathrm{a}}$ & 382,575 \\
\hline Carinotetraodon travancoricus & & WG & VU & 946,050 \\
\hline Channa aurantimaculata & Orange-spotted Snakehead & $\mathrm{EH}$ & $\mathrm{DD}^{\mathrm{b}}$ & 225 \\
\hline Danio jaintianensis & & $\mathrm{EH}$ & VU & 80 \\
\hline Dawkinsia arulius & Longfin Barb & WG & EN & Unknown ${ }^{\mathrm{e}}$ \\
\hline Dawkinsia rohani & & WG & VU & Unknown $^{\mathrm{e}}$ \\
\hline Devario assamensis & Bloodstripe Devario & $\mathrm{EH}$ & VU & Unknown ${ }^{\mathrm{e}}$ \\
\hline Etroplus canarensis & Banded Chromide & WG & $\mathrm{EN}^{\mathrm{c}}$ & 172 \\
\hline Garra hughi & Cardamom Garra & WG & $\mathrm{EN}^{\mathrm{d}}$ & 2245 \\
\hline Gonoproktopterus curmuca & & WG & EN & 60 \\
\hline Horabagrus brachysoma & & WG & VU & 150 \\
\hline Pethia manipurensis & Red Jasper Barb & $\mathrm{EH}$ & EN & Unknown $^{\mathrm{e}}$ \\
\hline Pethia shalynius & & $\mathrm{EH}$ & VU & 120 \\
\hline Pillaia indica & & $\mathrm{EH}$ & EN & 150 \\
\hline Puntius denisonii & Redlined Torpedo Barb & WG & EN & 310,791 \\
\hline Puntius chalakkudiensis & Denisonii Barb & WG & EN & \\
\hline Schismatorhynchos nukta & & WG & EN & 100 \\
\hline Tor khudree & & SA & EN & 10 \\
\hline
\end{tabular}

WG - Western Ghats; EH - Eastern Himalaya; SA - South Asia.

EN - Endangered; VU - Vulnerable; DD - Data Deficient.

a Known only from four fragmented locations (Dahanukar, 2011a).

b Known only from a single location (Chaudhry, 2010).

c Known only from two locations (Ali, 2011b).

${ }^{d}$ Known only from five locations (Ali, 2011a).

e Species exported without species specific label and encountered at retail shops in Europe and Singapore. 
Table 3

List of threatened and conservation concern endemic freshwater fish species exported from India during April 2012.

\begin{tabular}{|c|c|c|c|}
\hline Species & Trade name & Endemism & IUCN status \\
\hline Batasio travancoria & Yellow Catfish & WG & $\mathrm{VU}^{\mathrm{b}}$ \\
\hline Dawkinsia tambraparniei & Glimmer Barb & WG & $\mathrm{EN}^{\mathrm{c}}$ \\
\hline Gonoproktopterus thomassi & Red Tailed Barb & WG & $\mathrm{CR}^{\mathrm{d}}$ \\
\hline Glyptothorax housei & Kalkkari Catfish & WG & $\mathrm{EN}^{\mathrm{e}}$ \\
\hline Laubuca fasciata & Fascinating Hatchet Fish & WG & $V^{f}$ \\
\hline Pseudosphromenus dayi & Spike Tail Paradise Fish & WG & $\mathrm{VU}^{\mathrm{g}}$ \\
\hline Tor putitora & Golden Mahseer & SA & $\mathrm{EN}^{\mathrm{h}}$ \\
\hline Mesonoemacheilus remadevii & New Malabar Loach & WG & $\mathrm{LC}^{\mathrm{i}}$ \\
\hline
\end{tabular}

a Based on imports into the US.

b Severely fragmented populations; area of occupancy of $1000 \mathrm{~km}^{2}$ and threatened by habitat loss.

c Restricted in occurrence to <five locations which are fragmented.

d Extremely restricted distribution with an area of occupancy of $\sim 10 \mathrm{~km}^{2}$.

e Area of occupancy of $<25 \mathrm{~km}^{2}$ and restricted to a single location.

f Area of occupancy $<30 \mathrm{~km}^{2}$.

g Occurs in $<10$ locations.

h Past population decline calculated at $50 \%$.

i Restricted distribution; known only from a highly protected National Park in the Western Ghats Abbreviations of endemism and distribution as per Table 2.

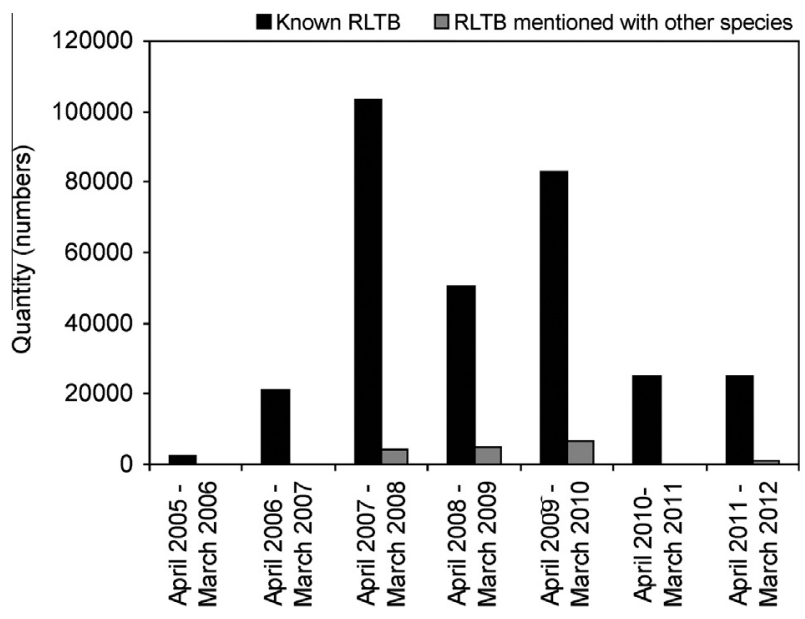

Fig. 3. Quantity of exports of the endangered Redline Torpedo Barbs (RLTBs) from India during the years 2005-2012.

disclosed that, a year after the ban was implemented; they altered trade routes by transporting RLTBs out of the state of Kerala by road to the Bangalore airport (in neighbouring Karnataka state), where the ban did not exist. Demonstrating this shift on the basis of quantitative data is impossible due to the poor record keeping at the airport in Kerala (COK/Kochi International Airport).

More than 15,000 KGS of aquarium fish were exported during 2005-2012 from Kochi airport without any species codes. Although Kochi is known to be a major hub for the exports of RLTBs (Raghavan et al., 2007, 2009), there was not a single labelled consignment of these fishes exported from the airport during 20052012.

During the 7 year period from 2005 to 2012, more than 89,000 RLTBs were collected and exported during their breeding season extending from October to March, which comprised $11-44 \%$ of the annual exports during these years (Fig. 5). As the trade in RLTBs is demand oriented with collections taking place only after an order is received, and taking into account that the maximum holding time of specimens post-collection and pre-export is 10-15 days, there is very little doubt that the fish were actually collected during their breeding months. Based on the available information on the size at first maturity for RLTBs ( $<4$ in.) (Solomon et al., 2011), it could be inferred that $46 \%(n=145,997)$ of the exports during the last 7 years comprised of specimens that are yet to reach first maturity.

\section{Discussion}

Effective monitoring and regulation of the aquarium industry is constrained by lack of accurate, quantitative and un-biased information (Green, 2003; Smith et al., 2008; Murray et al., 2012; Rhyne et al., 2012a). Trade figures for aquarium fishes are often non-existent, or if available are frequently mis-reported due to the exclusion or misclassification of shipment records (Olivier, 2001) or through inappropriate estimates by the exporting and importing companies (Rhyne et al., 2012a). The practice of shipment reporting by weight or value means that the number of individuals in trade is difficult to quantify (Wood, 2001). In addition, the lack of species-specific recording represents an impediment to assessing the origin and number of individuals of wild-caught species (Schlaepfer et al., 2005; Smith et al., 2008; Rhyne et al., 2012a).

Although there were no customs records showing the exports of 24 species, many specimens of four threatened cyprinids Dawkinsia arulius, D. rohani, Devario assamensis and Pethia manipurensis, confirmed to have come from India, were encountered in wholesale and retail shops in Germany and Singapore in 2010 and 2011. This is a clear indication that several threatened species are exported after 'mislabelling' or labelling under the general 'live ornamental fish' code.

\subsection{Trade in threatened species}

Aquarium trade is known to be a current, or potential future threat to at least 22 endemic freshwater fishes of India, of which 12 are already threatened (Appendix C). Several threatened species that are regularly exported from India have very restricted areas of occupancy (AOO). For example, B. striata, which occupies fragmented locations within a limited AOO of $400 \mathrm{sq} . \mathrm{km}$ (Dahanukar, 2011a), was one of the main species exported during 2005-2012. During this period, over 380,000 individuals where shipped from India. Similarly more than 2000 individuals of G. hughi, a rare and endangered stone sucker having an AOO of <300 sq. km (Ali, 2011a), were also exported during this period.

Apart from threats related to collection for the aquarium trade, all of the 30 threatened species that were exported are affected by a variety of additional stressors including large scale modifications to their habitats, i.e. sand mining, construction of dams and pollution from pesticides (Allen et al., 2010; Dahanukar, 2011). Seven 


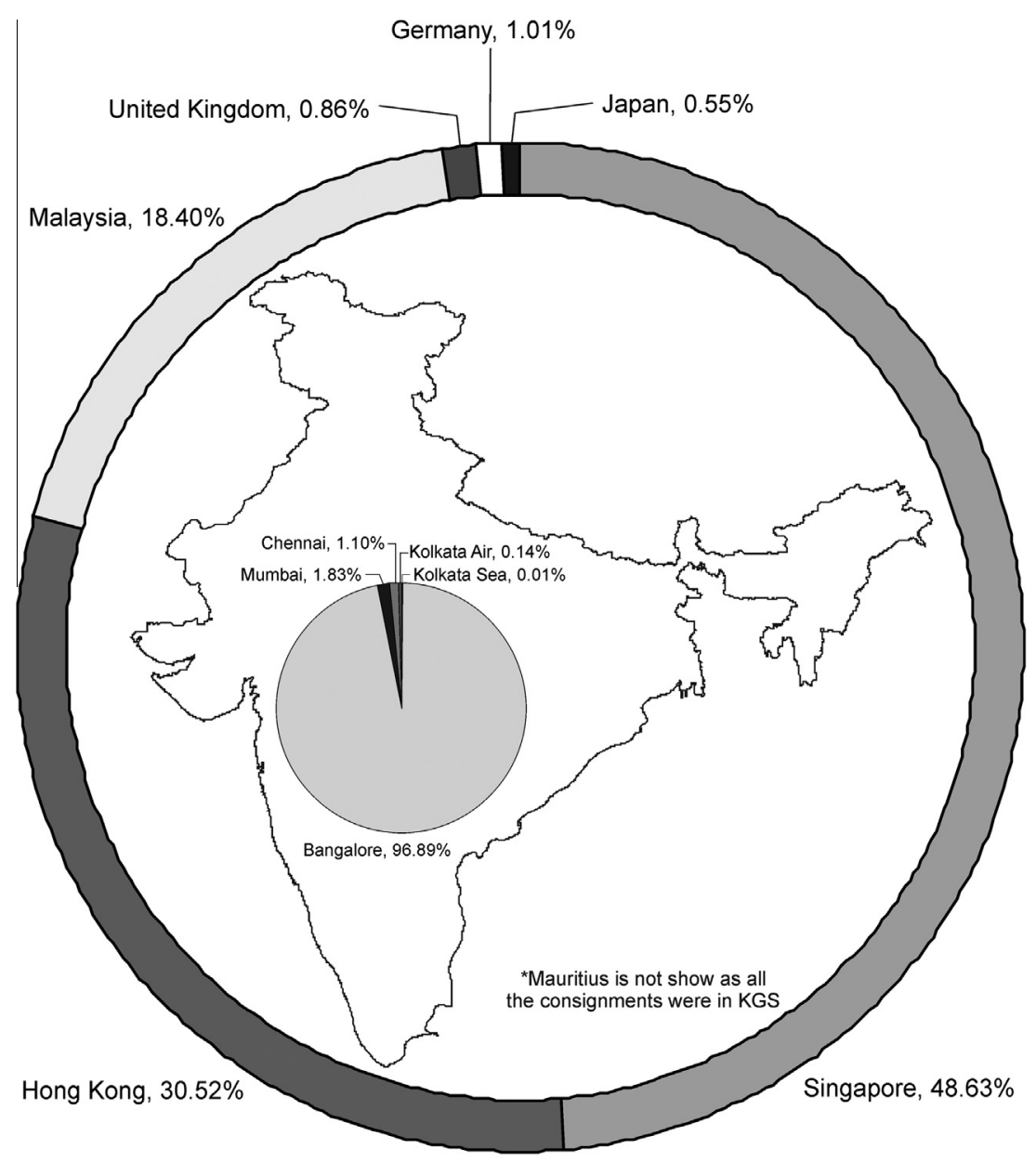

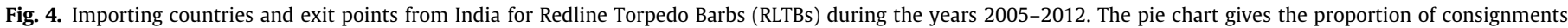

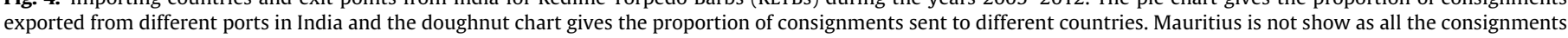
were in KGS.

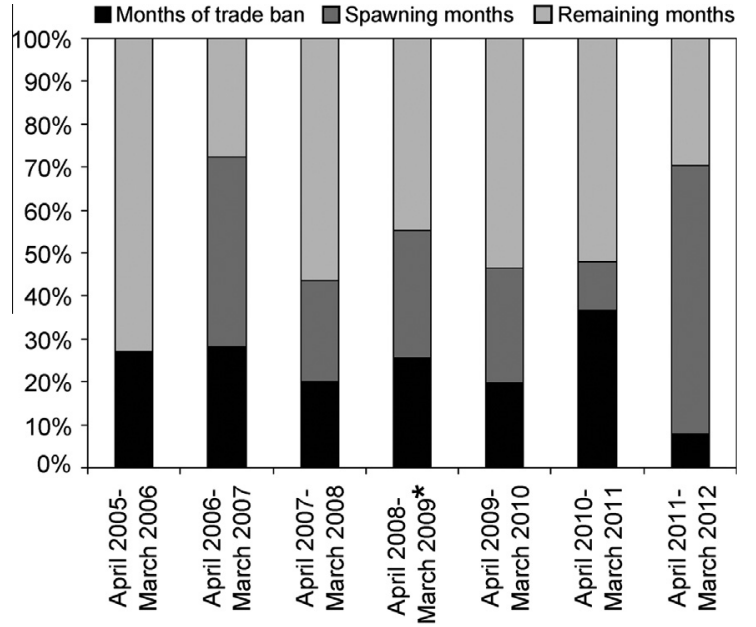

Fig. 5. Exports of Red Lined Torpedo Barbs (RLTBs) during their actual spawning season (January to March) and the mistimed seasonal closure/trade ban (June to October) during the years 2005-2012*. This figure shows the percentage of exports that took place during the months of the existing trade ban from 2009 to 2012.

species (C. aurantimaculata, Gonoproktopterus curmuca, G. thomassi, Horabagrus brachysoma, H. nigricollaris, Schismatorhynchos nukta and Tor khudree) are also important food fishes that are targeted by both commercial and artisanal fishers in their native range; juveniles being collected for the pet trade. Such species are often subjected to indiscriminate fishing including the use of unscientific practices such as dynamiting (Kharat et al., 2003; Dahanukar, 2011; Raghavan et al., 2011; Prasad et al., 2012). Nine of the 20 threatened species that were exported during 2005-2012 show a continuing decline in their populations (see species specific accounts in the IUCN Red List of Threatened Species).

In spite of such threats, India does not possess a legal instrument that protects freshwater fishes per se. The Wildlife Protection Act of India (WPA) 1972 (with amendments in 2002, 2006, 2009), the focal legislation for protection of threatened flora and fauna in the country, does not have a single freshwater fish species listed in its appendices (Raghavan, 2010; Dahanukar, 2011). Terrestrial Protected Areas (PAs) may offer some protection as commercial aquarium fish collections and food fisheries are not permitted inside these PAs (excepting some reservoirs) vide the WPA. But such regulations are not always strictly enforced as evidenced by personal interviews with collectors $(n=5)$ who revealed that RLTBs are collected from drainages inside at least two PAs. Similarly, as populations of the endangered G. hughi are mostly found inside PAs of the Western Ghats (Ali, 2011a), there is a high possibility that the $\sim 2000$ G. hughi specimens exported were collected from one of the five PAs in which they occur. The laxity of enforcement is further evident as hundreds of specimens of the rare balitorid loach, Mesonoemacheilus remadevii, known only from a single location 
inside the highly protected Silent Valley National Park (Ali and Raghavan, 2011) were exported to the US during April 2012 (Table 3).

\subsection{Collection and export of RLTBS}

Since entering the aquarium trade, RLTBs have been the mainstay of India's aquarium fish exports. Fetching a retail price between $\$ 5$ and $\$ 20 /$ piece (or even higher), these immensely popular barbs were the focus of an intensive 'boom and bust' fishery with catastrophic impacts on several local populations (Raghavan et al., 2007, 2009). Catches from several traditional collection centers increased during the years 2003-2007 (Ali et al., 2011). Since then, studies based on abundance, catch per unit effort, local knowledge and genetics have all concluded that the RLTBs have been severely overfished and become rare at traditional collection sites (Kurup and Radhakrishnan, 2006; Lakra et al., 2007; Raghavan et al., 2009).

Due to the income it provides, various government agencies in India continue to encourage trade in native aquarium fishes including the RLTBs. This is either through the provision of subsidies and developmental assistance for exporters, or by undertaking exports themselves. Close to 150,000 RLTBs were known to be exported by the Kerala Aquatic Ventures International Limited (KAVIL), a joint undertaking with private industry and the Government of Kerala (Babu, 2011). Interestingly, these consignments were not recorded to the species level in the customs records, and could have been exported under the general label of 'live ornamental fishes'. Our quantification of RLTB exports (Fig. 3) should therefore need to be considered as conservative estimates by at least 150,000 individuals.

\subsection{Export markets for RLTBS}

Lower freight charges, short duration of transport and frequent connectivity are the factors that determine the export markets for Indian aquarium fishes (Sekharan and Ramachandran, 2006). The South East Asian markets of Singapore, Hong Kong and Malaysia together imported $\sim 98 \%$ of all RLTBs exported from India. Singapore is known to be a hub for the global trade in aquarium pets (Collins et al., 2012) where fish imported from various parts of South and South East Asia are then re-packed and exported to the US and the European Union. Smith et al. (2008) reports that $45 \%$ of all freshwater fishes imported in the US came from these three countries.

Conservation benefits of wild capture and captive rearing in the aquarium trade have been the focus of several discussions (see Tlusty, 2002; Rosser, 2003). Concerns have been raised on the long term effects of unregulated trade in endemic freshwater fishes including RLTBs on the loss of genetic property rights (Raghavan et al., 2007; Raghavan, 2010). Although there is some information about the development and commercialization of captive breeding operations for RLTBs in South East Asia (Mittal, 2009), this has not fully eased pressure on wild stocks, as capture of wild RLTBs continue till date. Nevertheless, whether the apparent decline in export figures of wild caught RLTBs over the years is a result of the increased production in South East Asia, need to be examined in more detail. Furthermore, the importance of wild RLTBs needs to be assessed in supporting the entire Indian aquarium fishery. Ornamental fisheries are often comprised of a few key endemic species, with more commonly, widely available species being filler for the orders (Rhyne et al., 2012a). However, often, these fisheries can help provide protection to extant ecosystems (Tlusty et al., 2008), and thus each species within a fishery, as well as the entire fishery needs to be evaluated for its overall role in supporting a fully functioning social-ecological system (Tlusty, 2002; Tlusty et al., 2013; Rhyne et al., 2012b).

\subsection{Implications of trade on conservation of RLTBS}

Due to its high post harvest mortality (Ramachandran et al., 2004), an extremely low fecundity and skewed sex ratio in the wild, RLTBs have been suggested to be unsuitable for wild collection (Solomon et al., 2011). Yet, the trade shows no signs of slowing down as several thousands of RLTBs were exported in the first 3 months of 2012.

The suite of management plans initiated by the State Government of Kerala to protect the wild stocks of RLTBs has been largely flawed, and poorly enforced. Firstly, the spawning seasons of these fishes were miscalculated and the seasonal closures mistimed (Solomon et al., 2011). Secondly, the catch size recommended by the government encouraged the collection of large spawning individuals instead of juveniles. And finally by restricting the trade regulation to one of the two states from where the fish is collected and exported, the authorities allowed exporters to change trade routes and adapt through the state with less restrictive rules.

From mid 2006 until late 2008 (before the ban came into effect), higher quantities of 'RLTBs' were exported compared to those under the general label of 'live ornamental fishes' (i.e., un-named species). However, since late 2008/early 2009, the numbers of 'RLTBs' decreased while that of 'live ornamental fishes' increased considerably (Fig. 6) and equivalently. We speculate that one of the main reasons for this shift is because exporters began to stop labelling RLTBs and instead used a general 'live ornamental fish' label for exporting these endangered barbs. The export consignment of RLTBs from KAVIL (discussed above) was a probable example of such purposeful masking and mislabelling.

\subsection{Challenges and options for management}

One of the prime requisite for responsible aquarium fisheries and trade is monitoring and record keeping (Rhyne et al., 2012a). Increasing government's capacity to monitor collections and trade has been long recommended as one of the critical needs for the industry (Moreau and Coomes, 2006), but continues to be neglected worldwide.

In the case of India, fishes were screened for their potential in the aquarium industry on the basis of features that made them

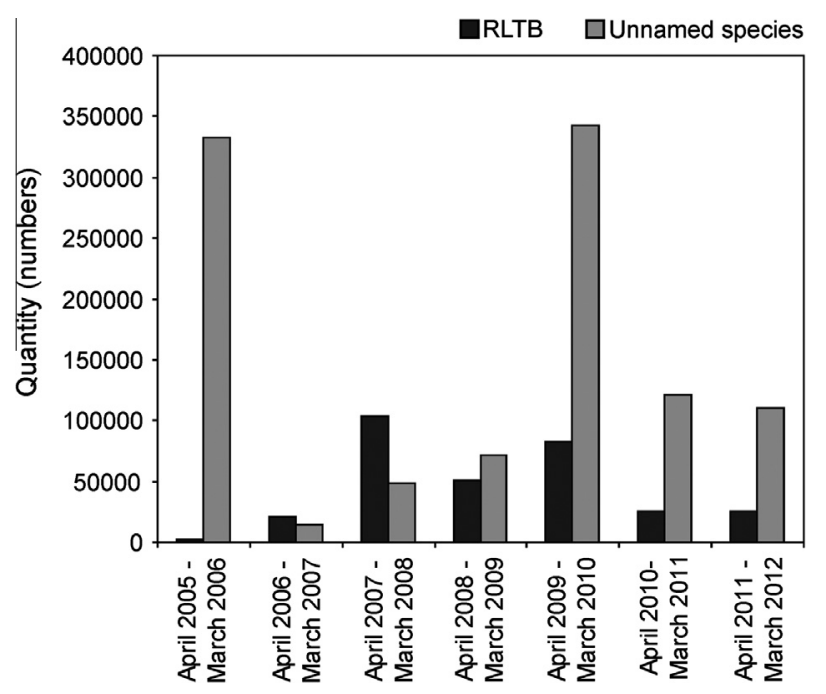

Fig. 6. Comparative account of the quantity of RLTB and un-named species exported from India during the years 2005-2012. 
desirable for the trade, but not apparently on the basis of biological features that would make them robust to trade. Deciding which species should feature in the trade and the manner in which they are to be sourced (wild caught or captive bred) (Tlusty, 2002; Tlusty et al., 2013) should be the first step for a sustainable aquarium industry in India. Even a very recent list of potential freshwater species for certification and geographical indication prepared by the MPEDA (Silas et al., 2011) contains several threatened species with a restricted range, including those found only inside protected areas. We strongly recommend that any current and future list of potential aquarium fishes for trade should avoid including species that are threatened with extinction, and additionally call for a listing of the threatened species that are currently in the trade under the national legislation (the WPA). In addition, species level information needs to be collected upon export at all the airports in the country to reduce the potential for endangered species to be categorized and labelled under a general export code. Currently, this is being followed at the Bangalore Airport.

An organized coding system (see Gerson et al., 2008), for freshwater aquarium fish, especially wild caught species which should include all information including species name, capture location, size of the specimens, and the names of collector and exporter should also be developed and adopted at all exit points. However, mere collection of these data are not sufficient to assure the harvest of ornamental fish are conducted in a manner that does not lead to further declines in wild species abundance. It is critical to assess the trade data for veracity, and also to annually report on the number and diversity of species being traded (Rhyne et al., 2012a). Only through the collection and appropriate analysis of trade data, will it be possible to make any assurance that appropriate measures are being sufficiently implemented to deliver wild sourced fish for the home aquarium hobby that have full societal and ecological benefits (Tlusty et al., 2013).

Fishers' compliance and support are also essential to any conservation action for exploited species (Vincent et al., 2011). Regulation of collections and exports of aquarium fishes although existent in many countries including India are deeply resented (Moreau and Coomes, 2006, 2007; Mittal, 2009), mainly because they follow a top-down approach of management with little or no stakeholder participation (DAFF, 2005; Raghavan, 2010). In India, the multiple ownership of key aquatic habitats and their jurisdictional complexities, presents yet another challenge (Raghavan et al., 2011). Aquatic habitats inside forest areas are controlled by the Forest and Wildlife Department, while 'fishes' and 'fisheries' per se are subjects of the Fisheries Department. As most of the aquarium species are forest-based fish, monitoring and enforcement can only be successful if multiple custodians work in unison, which has seldom been the case. An increased collaboration between authorities and stakeholder participation is therefore vital (Phelps et al., 2010). Furthermore, the management of fisheries has historically tended to be separated from the management of terrestrial resources. Whilst wildlife and forest departments have increasingly seen a shift in emphasis of their responsibilities from production to conservation, the primary focus of fisheries departments is still economic production albeit in terms of sustainable fisheries.

\section{Conclusions}

Although many international aquarium trade organizations advocate environmentally responsible practices, and consider collecting endangered species as bad for the industry (Hensen et al., 2010), they have not been widely acknowledged. A well-managed and responsible aquarium fishery can create livelihood opportunities and a sense of environmental stewardship for thousands of local communities in rural and often remote locations (see UNEPWCMC, 2008; Rhyne et al., 2012b). However, there is a pressing need to understand, and find solutions for the many challenging issues discussed above.

To fully understand the trade of any wild caught species, a large amount of information is needed. The health of the populations (e.g. stock assessments), the number of fish being harvested, and the link between these two are primary components for deriving any management plan focused on sustainability. Collection and trade of wild-caught freshwater fishes is one of the least understood facets of the aquarium industry, as little quantitative data exist on the number and composition of species involved (Moreau and Coomes, 2006, 2007; Collins et al., 2012), or stock assessments of the wild populations. There is also no information on the total value of the wild-caught freshwater aquarium fish trade. The data presented within focus is on the latter aspect of this equation, that being how many fish are collected and exported. This is a choke point in the trade chain where data can be aggregated. However, to fully understand this trade, it will be likely as important to understand the size and replenishment capabilities of the wild populations.

In spite of these data-deficiencies mentioned above, it has been speculated that total number of wild-caught freshwater fishes in the trade might probably far exceed wild-caught marine fishes (Gerstner et al., 2006). For example, 40\% of freshwater fishes imported in the US were sourced from wild populations, with these numbers considered an underestimate (Smith et al., 2008). It is known that 9-36 million fishes are collected and exported annually from the Amazon (Anjos et al., 2009; Gerstner et al., 2006; Moreau and Coomes, 2007). At one point in time, over 30 million individuals of a single species, the cardinal tetra, Paracheirodon axelrodi was exported from the Rio-Negro floodplains of the Amazon (Chao et al., 2001). Similarly, Kottelat and Whitten (1996) estimated that around 10,000,000 individuals of the clown loach, Botia macracanthus were exported from Indonesia. This compares to the 11 million marine fish the United States imports in a single year representing approximately $60 \%$ of the entire marine trade (Rhyne et al., 2012a). Around 291 species of African freshwater fishes are also known to occur in the aquarium trade (UNEP-WCMC, 2008), but without any quantification.

However, for such intense collection pressure, genetic investigations on the highly collected cardinal tetra indicate high levels of variability suggesting very large source populations (Beheregaray et al., 2004; Cooke and Beheregaray, 2007; Cooke et al., 2009). While a significant number of animals are collected from the wild, initial indications are that these r-selected species are resilient to this pressure. Yet moving forward, it will be very important to assess the status of wild stocks to assure the level of take indicated by the export data presented here does not lead to population declines.

The information here complements a number of prior studies that assess the trade of live fish for the aquarium and the lack of appropriate tracking and statistics for the hobby (Smith et al., 2008; Rhyne et al., 2012a,b). Overall, we believe that our study contributes to this body of work, by documenting the exports of endangered and threatened freshwater fishes for the pet trade from two global biodiversity hotspots. This will help create awareness and a foundation for effective monitoring, regulation and management of aquarium fisheries and trade worldwide, and lead to the development of a blue print for a self-sustained and responsible wild-caught aquarium industry.

\section{Acknowledgements}

The authors thank Diogo Veríssimo, Arun Kanagavel, Benjamin Lee, and Siby Philip for comments and suggestions on the draft 
manuscript; Scott Dowd, Fibin Baby, M.R. Ramprasanth, Anvar Ali, Josin Tharian, Benno Pereira and Priyanka Iyer for useful discussions; and Ambily Nair, Jorg Freyhof and Mithun Sukumaran for their help during visits to retailers. Critical comments and suggestions by two anonymous reviewers greatly improved the manuscript. The first author thanks the University of Kent, Canterbury, UK for a Post Graduate Research Scholarship; University of Hasselt, Diepenbeek, Belgium for a scholarship through the Special Research Fund (BoF), and the North of England Zoological Society (NEZS) - Chester Zoo, UK for funding field work.

\section{Appendix A}

List of exit and import points (airports and seaports) for wild caught freshwater aquarium fishes from India during the years 2005-2012.

Importing countries and airports/seaports

1. Bahamas

2. Bahrain

3. Czech Republic [Ruzyne/PRG]

4. Denmark [Copenhagen/CPH]

5. France ${ }^{\mathrm{a}, \mathrm{b}}$ [Paris/CDG, Toulouse/TLS]

6. Germany ${ }^{\mathrm{a}, \mathrm{b}}$ [Frankfurt/FRA, Hamburg/HAM]

7. Hong Kong ${ }^{\mathrm{a}, \mathrm{b}}$ [Hong Kong/HKG]

8. Italy [Venice/VCE, Milan/MXP]

9. Japan ${ }^{\mathrm{a}, \mathrm{b}}$ [Tokyo/NRT; Osaka/ITM]

10. Kuwait [Kuwait/KWI]

11. Libyan Arab Republic

12. Malaysia ${ }^{\mathrm{a}, \mathrm{b}}$ [Kuala Lumpur/KUL]

13. Mauritius [Port Louis/MRU] [Port Louis Seaport]

14. Netherlands [Amsterdam/AMS]

15. Portugal [Porto/OPO]

16. Romania

17. Saudi Arabia

18. Singapore ${ }^{\mathrm{a}, \mathrm{b}}$ [Singapore/SIN]

19. South Africa [Johannesburg/JNB]

20. South Korea

21. Spain [Barcelona/BCN]

22. Switzerland

23. Taiwan [Taipei/TSA]

24. Thailand ${ }^{\mathrm{a}}$ [Bangkok/BKK]

25. Uganda [Entebbe/EBB]

26. United Kingdom ${ }^{\mathrm{a}, \mathrm{b}}$ [London Heathrow/LHR, Manchester/ MAN, London Gatwick/LGW]

27. United States of America [Chicago/ORD; Los Angeles/LAX]

Indian exit Points [Airports/Seaports]

1. Bangalore Airport/BLR

2. Chennai Airport/MAS

3. Chennai Seaport/INMAA

4. Kochi Airport/COK

5. Kolkata Airport/CCU

6. Kolkata Seaport/INCCU

7. Mumbai Airport/BOM

a Exports of threatened species (excluding Red Lined Torpedo Barbs).

b Exports of Red Lined Torpedo Barbs.

\section{Appendix B}

List of wild caught freshwater fishes exported from India during 2005-2012 and their threat status.

\begin{tabular}{|c|c|}
\hline Species & IUCN Threat Status \\
\hline Aborichthys elongatus & Least Concern \\
\hline Acanthocobitis botia & Least Concern \\
\hline Acanthocobitis pavonacea $^{a}$ & Not Evaluated \\
\hline Amblyceps mangois & Least Concern \\
\hline Anguilla bengalensis & Least Concern \\
\hline Aplocheilus blockii & Least Concern \\
\hline Aplocheilus panchax & Least Concern \\
\hline Badis assamensis & Data Deficient \\
\hline Badis badis & Least Concern \\
\hline Badis blosyrus & Least Concern \\
\hline Badis kanabos & Data Deficient \\
\hline Badis ruber & Least Concern \\
\hline Bagarius yarelli & Near Threatened \\
\hline Bangana dero & Least Concern \\
\hline Barilius bakeri & Least Concern \\
\hline Barilius barila & Least Concern \\
\hline Barilius canarensis & Endangered \\
\hline Barilius gatensis & Least Concern \\
\hline Batasio travancoria $^{\mathrm{b}}$ & Vulnerable \\
\hline Botia lohacata & Not Assessed \\
\hline Botia rostrata & Vulnerable \\
\hline Botia striata & Endangered \\
\hline Carinotetraodon travancoricus & Vulnerable \\
\hline Carinotetraodon imitator & Data Deficient \\
\hline Chaca chaca ${ }^{\mathrm{a}}$ & Least Concern \\
\hline Chanda nama ${ }^{a}$ & Least Concern \\
\hline Chandramara chandramara & Least Concern \\
\hline Channa amphibeus & Least Concern \\
\hline Channa aurantimaculata & Data Deficient \\
\hline Channa barca & Data Deficient \\
\hline Channa bleheri & Near Threatened \\
\hline Channa gachua & Least Concern \\
\hline Channa harcourtbutleri & Near Threatened \\
\hline Channa punctata & Least Concern \\
\hline Channa stewartii & Least Concern \\
\hline Channa striata & Least Concern \\
\hline Chela cachius & Least Concern \\
\hline Crossocheilus latius & Least Concern \\
\hline Danio dangila & Least Concern \\
\hline Danio jaintianensis & Vulnerable \\
\hline Danio meghalayensis & Not Assessed \\
\hline Danio rerio & Least Concern \\
\hline Dario dario & Data Deficient \\
\hline Dawkinsia arulius $^{\mathrm{c}}$ & Endangered \\
\hline Dawkinsia filamentosus & Least Concern \\
\hline Dawkinsia rohanic $^{\mathrm{c}}$ & Vulnerable \\
\hline Dawkinsia tambraparniei $^{\text {b }}$ & Endangered \\
\hline Devario assamensis $^{\mathrm{c}}$ & Vulnerable \\
\hline Devario devario & Least Concern \\
\hline Devario malabaricus $^{\mathrm{a}}$ & Least Concern \\
\hline Dravidia fasciata & Least Concern \\
\hline Dravidia melanampyx & Not Assessed \\
\hline Esomus danricus & Least Concern \\
\hline Etroplus canarensis & Endangered \\
\hline Etroplus maculatus & Least Concern \\
\hline Etroplus suratensis & Least Concern \\
\hline Exostoma labiatum $^{\mathrm{a}}$ & Least Concern \\
\hline Gagata cenia & Least Concern \\
\hline Gagata gagata $^{a}$ & Least Concern \\
\hline Garra bicornuta & Near Threatened \\
\hline Garra gotyla & Least Concern \\
\hline Garra hughi & Endangered \\
\hline
\end{tabular}


Appendix B (continued)

\begin{tabular}{|c|c|}
\hline Species & IUCN Threat Status \\
\hline Gara lissorhynchus & Least Concern \\
\hline Garra nasuta & Least Concern \\
\hline Garra rufa & Not Assessed \\
\hline Gogangra viridescens & Least Concern \\
\hline Gonoproktopterus curmuca & Endangered \\
\hline Gonoproktopterus jerdoni & Least Concern \\
\hline Gonoproktopterus thomassi $\mathrm{i}^{\mathrm{b}}$ & Critically Endangered \\
\hline Glyptothorax cavia & Least Concern \\
\hline Glyptothorax housei ${ }^{\mathrm{b}}$ & Endangered \\
\hline Glyptothorax telchitta $^{a}$ & Least Concern \\
\hline Hara horai & Least Concern \\
\hline Hara jerdoni & Least Concern \\
\hline Hemibagrus menoda & Least Concern \\
\hline Horabagrus brachysoma & Vulnerable \\
\hline Horabagrus nigricollaris ${ }^{a}$ & Endangered \\
\hline Horadandia atukorali $^{\mathrm{a}}$ & Least Concern \\
\hline Labeo boga & Least Concern \\
\hline Labeo calbasu & Least Concern \\
\hline Laubuca dadiburjori & Least Concern \\
\hline Laubuca fasciata ${ }^{\mathrm{b}}$ & Vulnerable \\
\hline Laubuca laubuca $^{\mathrm{a}}$ & Least Concern \\
\hline Lepidocephalichthys guntea & Least Concern \\
\hline Macrognathus aral & Least Concern \\
\hline Macrognathus aculeatus & Not Assessed \\
\hline Macrognathus pancalus & Least Concern \\
\hline Mastacembelus armatus & Least Concern \\
\hline Mesonoemacheilus remadevii ${ }^{\text {b }}$ & Least Concern \\
\hline Microphis deocata & Near Threatened \\
\hline Monopterus albus & Least Concern \\
\hline Mystus bleekeri & Least Concern \\
\hline Mystus tengara & Least Concern \\
\hline Mystus vittatus & Least Concern \\
\hline Nandus andrewi $\mathrm{i}^{\mathrm{a}}$ & Data Deficient \\
\hline Nandus nandus & Least Concern \\
\hline Nemacheilus corica & Not Assessed \\
\hline Nemacheilus denisoni ${ }^{\mathrm{a}}$ & Least Concern \\
\hline Nemacheilus guentheri & Least Concern \\
\hline 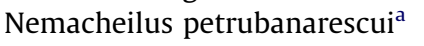 & Endangered \\
\hline Nemacheilus triangularis & Least Concern \\
\hline Neolissochilus hexagonolepis & Near Threatened \\
\hline Notopterus notopterus & Least Concern \\
\hline Olyra longicaudata & Least Concern \\
\hline Oreichthys cosuatis & Least Concern \\
\hline Oreichthys crenuchoides & Data Deficient \\
\hline Oryzias melastigma & Least Concern \\
\hline Osteobrama cotio & Least Concern \\
\hline Osteochilichthys nashii ${ }^{a}$ & Least Concern \\
\hline Pangio pangio & Least Concern \\
\hline Parambassis thomassi & Least Concern \\
\hline Parambassis wolffii & Least Concern \\
\hline Pethia conchonius & Least Concern \\
\hline Pethia gelius & Least Concern \\
\hline Pethia manipurensis ${ }^{c}$ & Endangered \\
\hline Pethia phutunio & Least Concern \\
\hline Pethia shalynius & Vulnerable \\
\hline Pethia ticto & Least Concern \\
\hline Pillaia indica & Endangered \\
\hline Pisodonophis boro & Least Concern \\
\hline Pseudolaguvia shawi & Least Concern \\
\hline Pseudosphromenus cupanus & Least Concern \\
\hline Pseudosphromenus dayi ${ }^{\mathrm{b}}$ & Vulnerable \\
\hline
\end{tabular}

Appendix B (continued)

\begin{tabular}{|c|c|}
\hline Species & IUCN Threat Status \\
\hline Psilorhynchus homaloptera & Least Concern \\
\hline Puntius chalakkudiensis & Endangered \\
\hline Puntius denisonii & Endangered \\
\hline Puntius mahecola & Data Deficient \\
\hline Puntius sahyadriensis & Least Concern \\
\hline Puntius sophore & Least Concern \\
\hline Rasbora daniconius & Least Concern \\
\hline Rasbora rasbora & Least Concern \\
\hline Schismatorhynchos nukta & Endangered \\
\hline Schistura beavani & Least Concern \\
\hline Tor khudree & Endangered \\
\hline Tor putitora ${ }^{\mathrm{b}}$ & Endangered \\
\hline Tor tor & Near Threatened \\
\hline Tetraodon cutcutia & Least Concern \\
\hline Tetraodon biocellatus & Least Concern \\
\hline Travancoria elongata $^{a}$ & Endangered \\
\hline Travancoria jonesi ${ }^{\mathrm{a}}$ & Endangered \\
\hline Wallago attu & Near Threatened \\
\hline
\end{tabular}

a Indicate species absent in the customs records but recorded as being in the trade by collectors and exporters.

b Indicate species absent in the customs records but recorded as imported to the US.

c Indicate species absent in the customs records but encountered in retail shops in Germany and Singapore.

\section{Appendix C}

Endemic freshwater fishes of India for which aquarium collections are known to be one of the major threats. ${ }^{a}$

\begin{tabular}{|c|c|c|}
\hline Species & Distribution & IUCN status \\
\hline Badis assamensis & $\begin{array}{l}\text { Eastern } \\
\text { Himalaya }\end{array}$ & Data Deficient \\
\hline Barilius canarensis & Western Ghats & Endangered \\
\hline $\begin{array}{l}\text { Betadevario } \\
\text { ramachandrani }\end{array}$ & Western Ghats & Data Deficient \\
\hline Botia rostrata & $\begin{array}{l}\text { Eastern } \\
\text { Himalaya }\end{array}$ & Vulnerable \\
\hline Carinotetraodon imitator & Western Ghats & Data Deficient \\
\hline $\begin{array}{l}\text { Carinotetraodon } \\
\text { travancoricus }\end{array}$ & Western Ghats & Vulnerable \\
\hline Channa bleheri & $\begin{array}{l}\text { Eastern } \\
\text { Himalaya }\end{array}$ & $\begin{array}{l}\text { Near } \\
\text { Threatened }\end{array}$ \\
\hline Dario Dario & $\begin{array}{l}\text { Eastern } \\
\text { Himalaya }\end{array}$ & Data Deficient \\
\hline Dawkinsia arulius & Western Ghats & Endangered \\
\hline Dawkinsia assimilis & Western Ghats & Vulnerable \\
\hline Dawkinsia tambraparniei & Western Ghats & Endangered \\
\hline Etroplus canarensis & Western Ghats & Endangered \\
\hline Garra surendranathanii & Western Ghats & Endangered \\
\hline Neolissochilus hexastichus & $\begin{array}{l}\text { Eastern } \\
\text { Himalaya }\end{array}$ & $\begin{array}{l}\text { Near } \\
\text { Threatened }\end{array}$ \\
\hline Parambassis lala & $\begin{array}{l}\text { Eastern } \\
\text { Himalaya }\end{array}$ & $\begin{array}{l}\text { Near } \\
\text { Threatened }\end{array}$ \\
\hline Pseudosphromenus dayi & Western Ghats & $\begin{array}{l}\text { Near } \\
\text { Threatened }\end{array}$ \\
\hline Puntius chalakkudiensis & Western Ghats & Endangered \\
\hline Puntius denisonii & Western Ghats & Endangered \\
\hline
\end{tabular}

(continued on next page) 
Appendix C (continued)

\begin{tabular}{lll}
\hline Species & Distribution & IUCN status \\
\hline Schistura devdevi & Eastern & Near \\
& Himalaya & Threatened \\
Schizothorax richardsonii & Eastern & Vulnerable \\
& Himalaya & \\
Syncrossus berdmorei & Eastern & Near \\
& Himalaya & Threatened \\
Travancoria elongata & Western Ghats & Endangered \\
\hline
\end{tabular}

a IUCN Red List of Threatened Species.

\section{References}

Ali, A., 2011a. Garra hughi. In: IUCN 2011. IUCN Red List of Threatened Species. Version 2011.2. <http://www.iucnredlist.org> (accessed 26.03.12).

Ali, A., 2011b. Etroplus canarensis. In: IUCN 2011. IUCN Red List of Threatened Species. Version 2011.2. <http://www.iucnredlist.org> (accessed 26.03.12)

Ali, A., Raghavan, R., 2011. Mesonoemacheilus remadevii. In: IUCN 2011. IUCN Red List of Threatened Species. Version 2011.2. <http://www.iucnredlist.org> (accessed 28.07.12).

Ali, A., Raghavan, R., Dahanukar, N., 2011. Puntius denisonii. In: IUCN 2011. IUCN Red List of Threatened Species. Version 2011.1. <http://www.iucnredlist.org> (accessed 19.02.12).

Allen, D.J., Molur, S., Daniel, B.A. (compilers), 2010. The Status and Distribution of Freshwater Biodiversity in the Eastern Himalaya. IUCN, Cambridge, UK and Gland, Switzerland; Zoo Outreach Organization, Coimbatore, India.

Anjos, H.D.B. dos, Amorim, R.M. de S., Siqueria, J.A., Anjos, C.R. dos, 2009. Ornamental fish export of the state of Amazonas, Amazon basin, Brazil. Bol. Inst. Pesca 35, 259-274.

Babu, K.A., 2011. Mathrubhumi Daily, Kochi, India, 21 November 2011 (in Malayalam).

Beheregaray, L.B., Moller, L.M., Schwartz, T.S., Chao, N.L., Caccone, G., 2004. Microsatellite markers for the cardinal tetra, Paracheirodon axelrodi, a commercially important fish from Central Amazonia. Mol. Ecol. Notes 4, 33332.

Brummet, R.E., Cargill, C., Lekunze, L.M., Puddister, D., 2010. Stream degradation, fish abundance and the potential viability of ornamental fisheries in southwestern Cameroon. Afr. J. Aquat. Sci. 35 (2), 155-164.

Chao, N.L., Petry, P., Prang, G., Sonneschien, L., Tlusty, M., 2001. Conservation and Management of Ornamental Fish Resources of the Rio Negro Basin, Amazonia, Brazil (Project Piaba). Universidade do Amazonas Press, Manaus, Amazonas, Brazil.

Chaudhry, S., 2010. Channa aurantimaculata. In: IUCN 2011. IUCN Red List of Threatened Species. Version 2011.2. <http://www.iucnredlist.org> (accessed 28.03.12).

Clarke, M., 2009. Why ban won't protect Puntius denisonii. Practical Fish Keeping Magazine http://www.practicalfishkeeping.co.uk/pfk/pages/sitemap.php/ show_article.php?article_id=717 accessed $19^{\text {th }}$ June 2009.

Collins, R.A., Armstrong, K.F., Meier, R., Yi, Y., Brown, S.D.J., Cruickshank, R.H., Keeling, S., Johnston, C., 2012. Barcoding and border biosecurity: identifying cyprinid fishes in the aquarium trade. PLoS ONE 7, e28381.

Cooke, G.M., Beheregaray, L.B., 2007. Extreme high variability in the S72 intron of the Amazonian cardinal tetra (Paracheirodon axelrodi). J. Fish Biol. 71, 132-140.

Cooke, G.M., Chao, N.L., Beheregaray, L.B., 2009. Phylogeography of a flooded forest specialist fish from Central Amazonia based on intron DNA: the cardinal tetra, Paracheirodon axelrodi. Freshw. Biol. 54, 1216-1232.

DAFF, 2005. A Strategic Approach to the Management of Ornamental Fish in Australia: Consultation Draft. Marine Coastal Committee and Natural Resources Standing Committee, Department of Agriculture, Fisheries and Forestry, Canberra, Australia, 38 p.

Dahanukar, N., 2011a. Botia striata. In: IUCN 2011. IUCN Red List of Threatened Species. Version 2011.2. <http://www.iucnredlist.org> (accessed 25.03.12).

Dahanukar, N., Raghavan, R., Ali, A., Abraham, R., Shaji, C.P., 2011 The status and distribution of freshwater fishes of the Western Ghats. pp 21-48. In: Molur, S., Smith, K.G., Daniel, B.A., Darwall, W.R.T (compilers) The status and distribution of freshwater biodiversity in the Western Ghats, India. IUCN, Cambridge, and Zoo Outreach Organisation, Coimbatore. 116p.

Eschmeyer, W.N., 2012. Catalog of Fishes Electronic Version (21/05/2012). <http:// research.calacademy.org/research/ichthyology/catalog/fishcatmain.asp $>$

FAO, 2003. Report on the Fourth Session of the Advisory Committee on Fisheries Research, Rome, 10-13 December, 2002. FAO Fisheries Report No. 699. Food and Agricultural Organization of the United Nations, Rome, 25 p.

Froese, R., Pauly, D., 2012. FishBase. <http://www.fishbase.org> (accessed 20.03.12).

Gerson, H., Cudmore, B., Mandrak, N.E., Coote, L.D., Farr, L.D., Baillargeon, G., 2008. Monitoring international wildlife trade with coded species data. Conserv. Biol. 22, 4-7.

Gerstner, C., Ortega, H., Sanchez, H., Graham, D.L., 2006. Effects of the freshwater aquarium trade on wild fish populations in differentially-fished areas of the Peruvian Amazon. J. Fish Biol. 68, 862-875.
Green, E., 2003. International trade in marine aquarium species: using the Global Marine Aquarium Database. In: Cato, J.C., Brown, C.L. (Eds.), Marine Ornamental Species: Collection, Culture, and Conservation. Iowa State Press, pp. 31-48.

Helfman, G., 2007. Fish Conservation: A Guide to Understanding and Restoring Global Aquatic Biodiversity and Fishery Resources. Island Press, 608 p.

Hensen, R.R., Ploeg, A., Fossa, S.A., 2010. Standard Names for Freshwater Fishes in the Ornamental Aquatic Industry. OFI Educational Publication 5. Ornamental Fish International, The Netherlands, 146 p.

Kharat, S.S., Dahanukar, N., Raut, R., Mahabaleshwarkar, M., 2003. Long term changes in the freshwater fish fauna in the northern Western Ghats, Pune. Curr. Sci. 84 (6), 816-820.

Kottelat, M., Whitten, T., 1996. Freshwater Biodiversity in Asia with Special Reference to Fish. World Bank Technical Paper No. 343. The World Bank, Washington, DC.

Kurup, B.M., Radhakrishnan, K.V., 2006. Indigenous ornamental fish resources of Western Ghats with special reference to Kerala. In: Souvenir Publication of Ornamentals Kerala, 5th and 6th February, 2006, Kochi, India, pp. 35-37.

Lakra, W.S., Mohindra, V., Lal, K.K., 2007. Fish genetics and conservation research in India: status and perspectives. Fish Physiol. Biochem. 33, 475-487.

MPEDA, 2010. Statistics of Marine Products Exports 2009. Marine Products Exports Development Authority. Government of India, Kochi.

Mittal, R., 2009. Business unusual: conserving Miss Kerala. Aquarama Mag. 12, 7-9.

Molur, S., Smith, K.G., Daniel, B.A., Darwall, W.R.T. (compilers), 2011. The Status of Freshwater Biodiversity in the Western Ghats. International Union for Conservation of Nature (IUCN) Gland, Switzerland and Zoo Outreach Organization (ZOO), Coimbatore, India, $116 \mathrm{p}$.

Moreau, M.-A., Coomes, O.T., 2006. Potential threat of the international aquarium fish trade to silver arawana Osteoglossum bicirrhosum in the Peruvian Amazon. Oryx 40, 152-160.

Moreau, M.-A., Coomes, O.T., 2007. Aquarium fish exploitation in western Amazonia: conservation issues in Peru. Environ. Conserv. 34, 12-22.

Murray, J.M., Watson, G.J., Giangrande, A., Licciano, M., Bentley, M.G., 2012 Managing the marine aquarium trade: revealing the data gaps using ornamental polychaetes. PLoS ONE 7, e29543.

Newing, H., 2010. Conducting Research in Conservation: Social Science Methods and Practice. Routledge, London.

Olivier, K., 2001. The Ornamental Fish Market. FAO/Globefish Research Programme vol. 67. United Nations Food and Agriculture Organisation, Rome.

Penning, M., Reid, G. McG., Koldewey, H., Dick, G., Andrews, B., Arai, K., Garratt, P., Gendron, S., Lange, J., Tanner, K., Tonge, S., Van den Sande, P., Warmolts, D. Gibson, C. (Eds.), 2009. Turning the Tide: A Global Aquarium Strategy for Conservation and Sustainability. World Association of Zoos and Aquariums, Bern, Switzerland.

Pethiyagoda, R., Meegaskumbura, M., Maduwage, K., 2012. A synopsis of the South Asian fishes referred to Puntius (Pisces: Cyprinidae). Ichthyol. Explor. Freshwaters 23 (1), 69-95.

Phelps, J., Webb, E.L., Bickford, D., Nijman, V., Sodhi, N.S., 2010. Boosting CITES Science 330, 1752-1753.

Prasad, G., Ali, A., Harikrishnan, M., Raghavan, R., 2012. Population dynamics of an endemic and threatened Yellow Catfish Horabagrus brachysoma (Günther) from Periyar River, southern Western Ghats, India. J. Threatened Taxa 4 (2), 23332342.

Raghavan, R., Prasad, G., Ali, A., Sujarittanonta, L., 2007. 'Boom and bust fishery' in a biodiversity hotspot - is the Western Ghats (South India) losing its most celebrated ornamental fish, Puntius denisonii, Day? Curr. Sci. 92, 1671-1672.

Raghavan, R., Prasad, G., Ali, A., Pereira, B., Sujarittanonta, L., 2009. Damsel in distress - the tale of Miss Kerala, Puntius denisonii (Day) an endemic and endangered cyprinid of Western Ghats biodiversity hotspot, India. Aquat. Conserv. Mar. Freshwater Ecosyst. 19, 67-74.

Raghavan, R., 2010. Ornamental fisheries and trade in Kerala. In: Sonnenschein, L., Benziger, A. (Eds.), Fish Conservation in Kerala. World Aquariums and Oceans Federation, St. Louis, USA, pp. 169-197.

Raghavan, R., Ali, A., 2011. Puntius chalakkudiensis. In: IUCN 2011. IUCN Red List of Threatened Species. Version 2011.2. <http://www.iucnredlist.org> (accessed 23.02.12)

Raghavan, R., Ali, A., Dahanukar, N., Rosser, A., 2011. Is the Deccan Mahseer, Tor khudree (Sykes 1839) (Pisces: Cyprinidae) fishery in the Western Ghats Hotspot sustainable? A participatory approach to stock assessment. Fish. Res. 110, 2938.

Ramachandran, A., Sekharan, M., Pramod, P.K., 2004. Freshwater Ornamental Fishes of Kerala, India and Their Potential and Captive Survival in Aquaria. 7th Asian Fisheries Forum, 30 November to 02 December, 2004, Penang, Malaysia (Abstracts)

Rhyne, A.L., Tlusty, M.F., Schofield, P.J., Kaufman, L., Morris Jr., J.A., 2012a. Revealing the appetite of the marine aquarium fish trade: the volume and biodiversity of fish imported into the United States. PLoS ONE 7 (5), e35808.

Rhyne, A.L., Tlusty, M.F., Kaufman, L., 2012b. Long-term trends of coral imports into the United States indicate future opportunities for ecosystem and societal benefits. Conserv. Lett. 5 (6), 478-485.

Rosser, A.M., 2003. Conservation benefits of wild capture and captive rearing in the ornamental fish industry. Ornamental Fish Int. (OFI) J. 43. <http:// www.ornamental-fish-int.org/data-area/conservation/untitled2/-conservationbenefits-of-wild-capture> (accessed 25.01.13).

Rowley, J.D., Emmet, D.A., Voen, S., 2008. Harvest, trade and conservation of the Asian Arowana Scleropages formosus in Cambodia. Aquat. Conserv. Mar Freshwater Ecosyst. 18, 1255-1262. 
Schlaepfer, M.A., Hoover, C., Dodd Jr., K., 2005. Challenges in evaluating the impact of the trade in amphibians and reptiles on wild populations. Bioscience 55, 256264.

Sekharan, M., Ramachandran, A., 2006. Threats in ornamental fish exports from India to Singapore. Seafood Export J. 2006, 11-17.

Silas, E.G., Gopalakrishnan, A., Ramachandran, A., Mercy, T.V.A., Sarkar, K. Pushpangadan, K.R., Kumar, A.P., Mohan, M.K.R., Anikuttan, K.K., 2011. Guidelines for Green Certification of Freshwater Ornamental Fish. The Marine Products Export Development Authority, Kochi, India, xii + 106 p.

Smith, K.F., Behrens, M.D., Max, L.M., Daszak, P., 2008. US drowning in unidentified fishes: scope, implications and regulations of live fish import. Conserv. Lett. 1 (2), 103-109.

Solomon, S., Ramprasanth, M.R., Baby, F., Tharian, J., Pereira, B., Tharian, J., Ali, A., Raghavan, R., 2011. Reproductive biology of Puntius denisonii (Day), an endemic and threatened freshwater aquarium fish of the Western Ghats and its implications for current and future conservation. J. Threatened Taxa 3, 20712077.
Tlusty, M.F., 2002. The benefits and risks of aquacultural production to the aquarium trade. Aquaculture 205, 203-219.

Tlusty, M., Dowd, S., Raghavan, R., 2008. Saving forests through the fisheries ornamental fishes as a route to avoid deforestation. Ornamental Fish Int. J. 56 , 21-25.

Tlusty, M.F., Rhyne, A.L., Kaufman, L., Hutchins, M., Reid, G.M., Andrew, C., Boyle, P., Hemdal, J., McGilvray, F., Dowd, S., 2013. Opportunities for public aquariums to increase the sustainability of the aquatic animal trade. Zoo Biol.

UNEP-WCMC, 2008. Monitoring of International Trade in Ornamental Fish. Background Information. United Nations Environment Programme-World Conservation Monitoring Center, Cambridge, UK, 40 p.

Vincent, A.C.J., Foster, S.J., Koldewey, H.J., 2011. Conservation and management of seahorses. J. Fish Biol. 78, 1681-1724.

Watson, I., Moreau, M.-A., 2006. The ornamental fish trade in support of livelihoods. Ornamental Fish Int. J. 50, 20-23.

Wood, E., 2001. Global advances in conservation and management of marine ornamental resources. Aquarium Sci. Conserv. 3, 65-77. 